Dr Deborah Mainwaring, (The Department of Education, Practice and Society, UCL Institute of Education, London, United Kingdom)

d.mainwaring@ucl.ac.uk

Telephone 02076126751

\title{
An exploration of the value placed on the content, interaction and incentive dimensions of learning by young people in post compulsory education.
}

Biographical note of author.

Dr Deborah Mainwaring is a Lecturer in Education at UCL Institute of Education. She was a secondary school teacher in a variety of subjects, including History, Psychology and Special Educational Needs. She has long standing interests in effective learning, motivation in learning, learner identity and the transition from compulsory education to the world of work. 


\begin{abstract}
The paper presents the findings of quantitative research that explores the value young people in post-compulsory education in England attach to three dimensions of learning. The dimensions of learning are the content dimension, the interaction dimension and the incentive dimension (Illeris 2007). Three hundred and thirty-one young people in four postcompulsory settings completed a purposefully designed questionnaire. The data was analysed using descriptive and inferential statistics. The findings indicated that the learners do value the dimensions of learning but they do not value them equally or consistently. The young people attach most value to the content dimension of learning. The results are considered in relation to the context of the assessment procedures of the English education system, young people's self- belief and learner identity, and the remit of the post-compulsory sector. It is argued that the post-compulsory sector is an integral part of an 'epistemic apprenticeship' (Claxton 2013, 3). This apprenticeship can be shaped to ensure that young people are equipped as learners to surmount the challenges of twenty first century living.
\end{abstract}

\title{
Key words
}

Post-compulsory. Dimensions of learning. Epistemic apprenticeship. Assessment. Learner identity. Self-belief.

\section{Introduction}

This paper presents the findings of research exploring the value that different young people in the post compulsory sector attach to the three dimensions of learning as proposed by Illeris $(2007,2015)$. The purpose of the research was to provide a snapshot of what aspects of learning, if any, young people articulate as worthy when they approach their learning. To capture this, there was a large sample and the questionnaire method was utilised. The paper is framed by three discourses. That of the post-compulsory education context, the concept of the epistemic apprenticeship and the three dimensions of learning.

\section{Post-compulsory education.}

In England, young people finish school at the end of Year 11, the year of their sixteenth birthday. They complete this compulsory general education with General Certificates of Secondary Education (GCSEs). The GCSEs are examinations that summatively assess the young people's performance in a range of subjects. English, Maths and Science are mandatory and young people complement these with several other selected subjects such as History, Geography and Art. Once the young people have been awarded their GCSEs, they are expected by law to continue their education or training until they are eighteen (DfE 2015). This Government policy was implemented in 2014. The intention of the policy is to support all young people to study beyond the age of sixteen, to provide wide opportunities and improve the overall standard of education of young people. (DfE 2015). It is envisaged that young people can choose different pathways in different contexts. There are further education colleges that provide vocational qualifications and prepare young people for the world of work. There are sixth form colleges that offer academic qualifications that prepare young people for Higher Education. Many schools have sixth forms attached to them and 
young people often choose to stay in a school setting. Indeed, in $2014,39 \%$ of the young people chose to continue their studies at a sixth form attached to a school. Thirty-four percent of young people went to Further Education Colleges and 13\% attended sixth form colleges (DfE 2015a). If the young people have achieved five GCSEs with grade $\mathrm{C}$ or above, the most commonly chosen qualification is the General Certificate of Education Advanced (A) Level (DfE 2015b). This is an academic qualification assessed by examination. An alternative qualification is the Business Education Technology Council (BTEC) Level 3 Diploma. This is regarded as a vocational qualification and can be taken in subjects such as Health and Social Care, Performing Arts or Hospitality and Catering. These programmes are assessed through coursework. Both the A level and the BTEC qualification pathways are designed to last two years. Some young people do not achieve five GCSEs with grade $\mathrm{C}$ or above. They too are expected to stay in education or training, either repeating their GCSEs or pursuing qualifications that are equivalent to them. Whatever pathway the young people take, it is intended that during this time, they will learn the knowledge and skills that prepare them for young adulthood and equip them for university or the world of work. These transitional years are considered critical for the development of young people so that they are enabled to take their place in society (Pring et al. 2009).

Regardless of the array of provision, the pathways available to those who are sixteen to nineteen years of age are regularly reviewed by consecutive governments because of concern that England's young people are ill prepared to work in the global economic context (DCSF 2008; Wolf 2011; BIS 2015; DfE 2016). It is purported that the young people lack the skills and knowledge expected of contemporaries in other nations (Pring et al. 2009; CBI 2015). There are repeated calls for the development of qualifications to improve skills and employability (Coffield 2007; Hodgson and Spours 2011). Presently, the Advanced Level qualifications are being reformed (DfE 2016).

\section{The epistemic apprenticeship.}

Yet it has been asserted that what matters in a rapidly changing world is the capacity of people to respond flexibly and creatively to the demands that will be made of them (Coffield 2002; Fredriksson and Hoskins 2007; Lucas and Claxton 2010; Claxton 2013). The unceasing qualification reform is inadequate because qualifications alone are not enough to ensure success for the future. Businesses want young people who are tenacious, have a readiness to take part, are open to new ideas, have a desire to learn and achieve (CBI 2015). As they go through their lives, young people will encounter complexity, uncertainty and difficulty. Their ability to learn through these challenges will be of paramount importance (Claxton 2013). It will require resilience, team-working, perseverance, flexibility and resourcefulness (Claxton 2002). Claxton $(2013,3)$ has labelled these capacities epistemic qualities and suggests that part of the process of schooling is to offer an expansive 'epistemic apprenticeship'. He argues that when schools and colleges explicitly imbue their cultures with an attitude of confidence in the face of difficulty then expansive epistemic identities can be nurtured in young people (Claxton 2006). The young people can develop the personal attitudes that enable them to learn in the face of challenge and concurrently expand their capacity to learn. 
For Watkins (forthcoming) the epistemic apprenticeship includes enabling young people to know themselves as learners. In formal learning environments this is encouraged through talking about learning, noticing learning, reflecting on learning and making learning a focus on learning (Watkins et al. 2007). These activities can enable young people to collaborate to construct their learning. There is considerable evidence that successful students take charge of their own learning and are able to choose appropriate strategies for learning in different contexts (Brown 1997; Watkins et al. 2007; McQueen and Webber 2013; Watkins forthcoming). Given that the late teenage years are considered to be crucial for identity formation (Erikson 1968; Illeris 2007), it seems that imbuing these years with explicit consideration of learning can be beneficial.

\section{The three dimensions of learning.}

Illeris (2015) has stated that a comprehensive theory of learning includes a content dimension an interaction dimension and an incentive dimension. The content dimension is what it is that is to be learned. It may be knowledge, skills, opinions or ways of behaving. Illeris (2007) explains the dynamic process of learning in the content dimension drawing on Piaget (1952) and Kolb (1984). Cognitive processes that enable the learner to learn are included. To acquire knowledge, learners may assimilate or accommodate information. Reflection is utilised so that meaning can be made from experiences and the learner changes in their capacity to deal with the challenges of practical life. The interaction dimension is engagement with the environment. This can be in the general societal situation that has pervasive cultures and values or in the immediate environment of the classroom and school or college. In this paper, the focus is on the interactions that happen in explicit learning situations. These are extensive and occur through social activity. Learners participate in groups of different sizes. They discuss their ideas in class and they share tasks. As they do so, they are engaged in the sharing of perceptions, ideas and activity. They may develop shared dialogue and shared meanings (Wenger 1998; Illeris 2007). The incentive dimension is the mobilisation of mental energy to drive the process - the will and motivation to learn. Although motivation may sometimes be unconscious, when a learner perceives knowledge to be worth learning, then motivation toward that learning will be evident. Illeris (2015) states that no learning process can be understood without considering all three dimensions. They are inter-dependent and dynamic.

It is suggested here that in his presentation of a comprehensive theory of learning, Illeris (2007, 2015) envelops the epistemic qualities that Claxton (2013) and Watkins (forthcoming) advocate. The cognitive dimension includes reasoning and reflection. The incentive dimension incorporates the need for resilience and perseverance. The interaction dimension envelops the pro-social collaborative aspects of learning. Illeris (2007) suggests that learners are continually drawing from the three dimensions of learning when they engage in learning. They are aware of the conditions required for learning and reflect on their learning (Illeris, 2007). Yet authors such as Claxton (2013) and Watkins (forthcoming) are determined that such qualities are made explicit in learning environments. This to counteract the prevailing view that learning is the narrow process of the acquisition of knowledge and to encourage expansive epistemic identities in young people. Epistemic identities that will enable them to overcome the learning challenges that they face. 
Ergo, the research here explores whether young people in the post compulsory sector articulate value for the three dimensions of learning. It is suggested that if young people have some awareness of the three dimensions of learning, and are able to articulate how they value them, they may be in a position to employ appropriate strategies in their learning. Applying the three dimensions through a research tool may cast a lens on emerging learning identities.

The research questions are:

1) Do young people in the post compulsory sector articulate value for the three dimensions of learning as outlined by Illeris (2007)?

2) Do young people show different value for the dimensions of learning as outlined by Illeris (2007)?

\section{Method.}

\section{The Sample.}

Three hundred and thirty-one young people from four different post-sixteen settings took part in the research. All the young people had completed compulsory schooling. They had embarked on particular pathways in preparation for university or work and would soon be entering the adult world. They were chosen because they were between 16 and 19 years of age and were coming to the end of a 'protracted epistemic apprenticeship' (Claxton 2013, 3). Their value for different aspects of learning might be emergent.

One hundred and thirty-four participants attended two sixth form centres attached to schools. Three of these participants were pursuing BTEC Level 3 qualifications. The rest were following A level courses. One hundred and ninety-seven participants attended two sixth form colleges. Sixty-five of these participants were pursuing A level courses. The rest were following a variety of BTEC courses at different levels. Both the sixth form centres and the sixth form colleges were co-educational. The representation of gender from each centre was balanced. Overall, one hundred and sixty-nine participants were female. One hundred and fifty-seven participants were male. Five participants did not report their gender identity. Although boys and girls approaches to learning and achievements can vary at different stages of their school and college career (OECD 2015) the primary focus of this study was to capture overall perceptions of young people at the specific transitional ages of sixteen to nineteen.

\section{The questionnaire.}

The questionnaire was specifically designed for the research. The questionnaire explored the value that the students gave to the different dimensions of learning that had been articulated by Illeris (2007). To construct the questionnaire, the procedures put forward by Rust and Golombok (2009) were adhered to. The questionnaire was piloted and developed through item analysis. Twenty-one statements were designed to capture the value given to the content dimension of learning. This included the value young people gave to their strategies for acquiring knowledge. Nineteen statements were designed to capture the value given to learning with others (the interaction dimension) and eighteen statements were designed to capture the value given to the motivation to learn (the incentive dimension). The statements included the opportunity for the participants to reflect on previous learning experiences and 
to consider future learning possibilities. The statement items were randomly ordered in the questionnaire. Students responded on a four-point rating scale to each statement. These were 'strongly disagree', 'disagree', 'agree', 'strongly agree'. These limited choices were intended to avoid ambivalence. Acquiescence in response was averted through a mix of positive and negative statements. The results tables show all the statement items.

\section{Procedure}

Firstly, the questionnaire was piloted and forty young people gave feedback on the quality of the survey sheet, the accessibility of the items and the time it took to complete the questionnaire. The final questionnaires were then administered to young people during two weeks in the summer of 2011. Through negotiation with host teachers, the researcher was able to access the students in their classrooms. The questionnaires took up to thirty minutes to complete.

\section{Analysis.}

The statistical package for the social sciences (SPSS) was used to analyse the findings. The mean scores and the standard deviations were found for all the items. The items for the different dimensions of learning were statistically compared.

\section{Ethics}

Ethical procedures were shaped by the British Psychological Society ethical guidelines (BPS 2006). Initially, permission was garnered from the principals of the four sites that had been chosen. The forty participants who completed the pilot questionnaire provided feedback on the sensitivity of the questions. They were not concerned. All the participants in the sample were briefed about the purpose and procedure of the research. Their consent was considered to be conditional throughout.

\section{Findings}

The findings will be presented in four sections. Firstly, the value expressed for the content dimension will be presented. This will be followed by the value expressed for the interaction dimension of learning. Thirdly, the value expressed for the incentive dimension of learning will be presented. Finally, the differences expressed for the three dimensions of learning will be compared.

\section{The content dimension of learning.}

Table 1. shows the responses to the statements designed to measure the content dimension of learning. It shows the frequencies in percentage form with which each item was responded to with strongly disagree (SD), disagree (D), agree (A), strongly agree (SA). The figures in brackets are the raw scores from the participants. The number of participants who responded to the statement overall is recorded $(\mathrm{N})$. The table shows the means score and the standard deviation for each items. The items are presented in descending mean order.

\section{Please put Table 1 here.}


It is of note that the means for the content dimension of learning were greater than two. The number of participants that strongly disagreed with any of the statements was consistently small. This indicates that overall the participants did value the content dimension of learning. Within this endorsement there were differences. The five highest means for the statements relating to the content dimension of learning were concerned with participants' perceptions of the future and the need to learn information to succeed. The statement with the highest mean score ( $\mathrm{M}=3.26$, SD., 79) was 'I am sure I will not need to learn new information to go forward in life'. This reversed statement was disagreed with by eighty-seven percent of the participants, forty-two percent of whom disagreed with it strongly. Two hundred and ninetyfive participants agreed or strongly agreed with the statement 'if I want to get a good job, or go to university, I'm going to need to show that I have lots of knowledge in my head'. Within the content dimension, statements had been constructed to capture students' behaviours for the acquisition of knowledge. These tended to generate lower means than those that assessed the value of knowledge. Therefore, the statement 'soon after a lesson I reread my notes to make sure I understand them' had a mean of 2.33 and an SD of .67. Just fifty-five percent of the participants agreed with the statement 'I tend to learn what is set, I usually don't do anything extra' $(\mathrm{M}=2.42, \mathrm{SD} ., 71)$. It is clear then from the items designed to capture the value attributed to the content of learning that the participants were very aware of the need for acquiring knowledge, this in relation to their expectation of what employers or university staff would value. They also reported having some cognitive strategies with which to approach the acquisition of knowledge. However, the latter was not as uniformly endorsed as the former.

\section{The interaction dimension of learning.}

\section{Please put Table 2 here.}

Table 2 shows the responses to the statements designed to measure the interaction dimension of learning. The format is similar to Table 1. As with the content dimension of learning, all the means were greater than two, indicating that the participants had value for the interaction dimension of learning. Interestingly, and mirroring the response for the content dimension of learning, the statement that scored the highest mean $(\mathrm{M}=3.33, \mathrm{SD}, .66)$ in this dimension was also related to future prospects. This was 'it is so competitive today that to get a good job you need to show you are really willing to work with others'. Ninety-two percent of participants agreed with this statement. Two hundred and sixty-eight participants agreed with the statement 'even though the times are tough, I think I will be able to get a good job because I show that I am willing to learn with others'. The adherence to these two statements indicates the young people's awareness for the value of learning with others in the working world. There is the possibility that they were expressing awareness that in employment, they would not be judged just on their knowledge, but also on their willingness to actively participate with others.

A further three statements with high means suggested that there was a strong appreciation to ask and be asked questions. Eighty-eight percent of the participants agreed with the 
statement 'I like it when teachers give us time to ask questions about stuff we don't understand' $(\mathrm{M}=3.23 \mathrm{SD}, .71)$. 'I know that being asked questions in class is good for my learning' was agreed with by $91 \%$ of the participants $(\mathrm{M}=3.20, \mathrm{SD}, 66)$. The reversed item 'I think if I ask a teacher or my friends a question it shows that I am not very smart' was disagreed with by $80 \%$ of the participants, suggesting that young people recognised this type of interaction as valuable for learning rather than as any form of measurement. Even so, the item 'I always ask questions if I need to understand something' had a mean of 2.89 (SD, .80) indicating that this acceptance of the value of questions did not consistently translate into learning behaviour.

Many participants recorded enjoying learning with others; eight-five percent of the participants agreed with the statement 'I like to learn with other people' $(\mathrm{M}=3.01, \mathrm{SD}, .64)$. Such appreciation did not always manifest into expected action. The mean score for 'when I want to learn something, I seek out friends to study with' was 2.53 (SD, .72) with just 55\% agreeing or strongly agreeing with this statement. Fifty-seven percent agreed or strongly agreed with the statement "when I am learning at home, I talk over what I am learning with my friends or parents $(\mathrm{M}=2.34, \mathrm{SD}, .82)$. It is possible that whilst participants enjoyed learning with others, they were ambivalent that doing so would be a productive aspect of the learning process.

\section{The incentive dimension of learning.}

Table 3 shows the responses to the statements designed to measure the incentive dimension of learning. The format is similar to Table 1. As with the content dimension of learning and the interaction dimension of learning, all the means were greater than two, indicating that the participants had positive value for the incentive dimension of learning.

\section{Please put Table 3 here.}

The item with the highest mean score in the statements for the incentive dimension of learning was explicitly related to motivation. Eighty-five percent of the participants agreed or strongly agreed with the statement 'I am motivated to be the best that I can be, just for myself $(\mathrm{M}=3.13, \mathrm{SD}, .68)$. The confirmation of high motivation was reiterated with the $77 \%$ disagreement rate for the statement 'I don't really want to be doing the course/s I am doing so staying motivated is difficult $(\mathrm{M}=2.99, \mathrm{SD}, .87)$. This item indicates that many of the participants were comfortable with the programmes they were following. Yet the agreement level for 'I am motivated to do well, so I try to work solidly all the way through the term' fell to $65 \%(\mathrm{M}=2.71, \mathrm{SD}, .74)$ and strikingly the agreement for 'I spend a lot of time finding out about new topics' fell to $39 \%(\mathrm{M}=2.37, \mathrm{SD}, .69)$.

The mean for 'I don't think that I need to be in the right mood to learn successfully' was 3.10 (SD, .79). This reversed statement indicated that 326 participants were aware that the emotions they had could impact on their learning. At the same time, seventy-five percent of the participants agreed with the statement 'to do my best when I am learning, I often take small breaks so that I can stay calm' $(\mathrm{M}=2.89, \mathrm{SD}, .77)$, thereby indicating that the participants had particular approaches to stay motivated whilst learning. 


\section{The differences between the statements for each dimension.}

Although it has been noted that the participants did value the dimensions of learning. It is evident that the mean scores for the items within the three dimensions of learning were different. The highest mean score $(\mathrm{M}=3.33, \mathrm{SD}, .66)$ was generated in the interaction dimension for learning and the lowest mean score $(\mathrm{M}=2.24, \mathrm{SD}, .99)$ was in the incentive dimension of learning. Therefore, the mean scores for the items measuring each different dimension of learning was established. This was done by taking into account the reversed scores, adding the scores of each item in a dimension together and dividing by the number of items. The results are shown in Table 4. It can be seen that the mean score generated for the items measuring the content dimension of learning $(\mathrm{M}=2.91, \mathrm{SD}, .25)$ was greater than the mean score for all the items measuring the interaction dimension of learning $(\mathrm{M}=2.88, \mathrm{SD}$, .29) which in turn was greater than the mean score for all the responses measuring the incentive dimension of learning $(\mathrm{M}=2.75, \mathrm{SD}, .26)$. Of note is the range of scores. This was greatest for the interaction dimension of learning where there was a high mean for the item capturing the idea of the need to learn with others in the future and a low mean for the item suggesting the need to learn on one's own if necessary (see Table 2). The contrast highlights the complexity of the participants' values towards aspects of learning.

\section{Please put Table 4 here.}

A repeated measures ANOVA demonstrated that the differences between the means was statistically significant $(\mathrm{F} 2,34)=55.87, \mathrm{p}<.05, \eta^{2}=.77$. The effect size of eta squared $\left(\eta^{2}\right)$ has been reported to show the proportion of variance that was related to the different groups (Green et al. 2000). An effect size of .77 indicates that the differences between the scores within the groups were small but the differences between the means were considerable (Field 2009). Such evidence indicates that for the participants in this study, the content dimension for learning was valued more highly than the social dimension for learning, which in turn was valued more highly than the emotional dimension for learning.

\section{Summary of findings.}

The findings are summarised in two parts. Firstly, the research questions will be answered. Secondly, other emergent findings will be put forward.

\section{Answering the research questions.}

To answer the first research question, it is evident that young people in the post compulsory sector do articulate value for the three dimensions of learning as outlined by Illeris (2007). This is because the mean response to all the items was always greater than two. The young people are cognisant of different aspects of the learning process and are able to judge which aspects they find most important. To answer the second research question, the evidence suggests that young people show different value for the different dimensions of learning. The content dimension of learning is most highly valued. The incentive dimension of learning is least highly valued. 


\section{Other findings.}

The young people recognised the value that the content dimension and the interaction dimension of learning may have on their futures as they learn at work or at university.

The young people appreciated the value of being asked and asking questions for their learning.

The young people endorsed the concept of knowledge, they endorsed the idea of learning with others and they recognised the importance of motivation but they were more ambivalent in their endorsement of strategies within the dimensions of learning that might support their learning.

\section{Discussion.}

At first glance, it appears that the young people have a comprehensive view of learning. Their response to the items on the questionnaire indicates that they recognise the different aspects that interact for learning and are able to articulate positive value for these. It can be suggested that their epistemic apprenticeship has enabled them to demonstrate cognisance for the multi-faceted nature of learning. Optimistically, this contrasts with the position of those who think that young people might have a restricted idea of learning (Coffield 2002; Watkins et al. 2007; Claxton 2013). However, Claxton (2013) has argued that being taught about something or becoming aware of something does not necessarily lead to a change in the habits for learning that are utilised. It is apparent here that whilst the young people can endorse the three dimensions of learning, they are not so certain in how to apply strategies to incorporate and inculcate these dimensions into their learning. They demonstrate ambivalence towards applying strategies that reinforce the dimensions of learning. The exception to this is with regard to asking and being asked questions in the interaction dimension. It is of note however, that although this is something that the participants recognise the value of unreservedly, it is only a small part of the many ways learners can actively participate in learning with other people. The value for the collaborative aspects of learning that Watkins et al. (2007) advocate are less apparent.

Further, it is of equal and concurrent concern here that the content dimension was valued most highly by the participants and the incentive dimension was valued least highly. These differences will now be considered. The preference for the content dimension will be discussed first.

\section{The preference for the content dimension.}

It has already been stated that young people finish their compulsory schooling in England with examinations and that these determine the pathways that are available to the young people in the post sixteen phase. It has been shown that most young people continue their education with courses that include examinations. Invariably, these examinations assess knowledge, the understanding of that knowledge and its application. This is the measurement of the content dimension of learning. Perhaps then, it is a consequence of the examination procedures in the English education system that leads to the content dimension of learning being valued most highly by the participants. It is possible that the performance criteria established in English pathways leads not to an appreciation of the comprehensive nature of 
learning, but to a narrowed perception. Concurring with other authors (Lucas and Claxton 2010; Claxton 2013), it is suggested here that this is not sufficient preparation for the uncertain futures expected. A future that includes actively learning and working with others, and finding ways to overcome unexpected challenges. These findings were garnered before young people in England had to participate in education and training until they were eighteen. Yet, if the ambitions of that policy are to be achieved, then pathways and programmes that encourage expansive epistemic apprenticeships are desirable.

\section{The under appreciation of the incentive dimension.}

For Illeris $(2007,78)$ learning is 'fundamentally libidinous'. Yet, in this research the participants attached the least value to the incentive dimension of learning. Drawing on Freud's (1962) concept of the defence mechanism, Illeris (2007) states that intended learning will not occur when learners are ambivalent or resistant to the learning. Although this may be to preserve an existing sense of self (Illeris 2007), this less positive response may indicate that participants are unsure how to manage themselves when they need to find the will to learn.

The interweaving of a learner's self-belief and their motivation has been well documented (Garcia and Pintrich 1994; Dweck 2006). If young people believe that through persistence they will be able to learn what they perceive to be challenging, firstly they are more likely to learn it and secondly they are more likely to learn more challenging information and skills from thereon in. The effect is cumulative. Dweck $(2006,7)$ has suggested that young people can be encouraged to have a 'growth mindset'. Claxton (2007) endorses this suggesting it is part of an expansive epistemic identity. Conversely, young people who are defending their self-belief through resistance or ambivalence may have restricted epistemic identities. In this research, seventy-six percent of the participants said that they were happy on their courses, leaving twenty-four percent who were not. It could be that for some of these learners there was a mismatch between what they were expected to learn and their motivation for it. This is problematic for two reasons. Firstly, learning can sometimes be unavoidably challenging. Resilience and perseverance are pre-requisites to an expansive epistemic identity and without these, learners might not be equipped for their twenty first century futures. Their learner identities may be restricted. Secondly, the variety of pathways available to the young people in the post-compulsory sector ought to lead them to study something that they are happy to engage with and be challenged by. This brings the discussion to the purpose of the postcompulsory sector.

\section{The remit of the post compulsory sector.}

In her influential report, Wolf (2011) stated that too many young people in England got little to no benefit from the post-16 education system. The government response to that report was further compulsion of English and Maths, more examinations and tighter performance accountability (DfE 2015c). This may do nothing to alter the situation that some young people are enrolled on courses that they do not feel motivated towards. It has been argued here that it is the preponderance of exams that encourages the preference for the content dimension of learning. The preponderance of exams may also negatively influence young people's drive to learn. In 2014, 36.2\% of young people did not achieve five GCSEs with grade $\mathrm{C}$ or above (DfE 2015b). Currently, they are expected to find the will to re-visit learning in pathways and structures where success has thus far eluded them. Yet, the overall 
standard of education may not improve if the pathways available to young people are presented in structures that the young people are already familiar with, and fail at. If more young people are to be supported to study (DfE 2015) then courses that provide a comprehensive experience of learning are pre-requisites for engagement. It seems that the regular reviews and policy reforms in the sector continually overlook the important element of epistemic apprenticeship, and negate the value of the interaction and incentive dimensions of learning. This is disheartening.

Nevertheless, although the young people's epistemic identities might be better nurtured, it is evident that in England the young people already show some awareness of their learning and do attach values to the different dimensions of learning. This is a good position on which to build. It is worth reiterating that late adolescence is a time of identity formation. As the sector that fits between schooling and the wider social and economic world, the post compulsory sector can play an important part in the continuing development of expansive epistemic identities in its learners. Indeed, regardless of government interference, the post compulsory sector continues to provide many different educational and training courses (DfE 2011). It is a dynamic part of education that offers myriad opportunities to young people (Hodgson 2015). In this research, the young people studied in four different contexts in differing localities. Moreover, whilst the participants studying A levels expected to be assessed through examination, the participants on the BTEC programmes expected to be assessed through coursework. There is the possibility that the different pathway choices and the differing contexts are connected to different values to the dimensions of learning. If young people are enrolled on programmes that incorporate the assessment of more than content, then their epistemic identities might expand. Policy makers might consider this as they aim to improve education for all and empower young people. Research is required to explore what factors might relate to the varied appreciation for the dimensions of learning. The factors include assessment procedures and gender, both of which will be examined in further papers.

\section{Summary.}

The science of learning is developing (Bransford et al. 2000). These findings capture a contained picture of what a sample of young people in the post compulsory sector value when they approach their learning. Although the analysis assumes that the items that were constructed for the questionnaire were a true reflection of the three dimensions of learning proposed by Illeris (2007), the findings provide a nuanced understanding of young people's preparedness for an adulthood of learning. It is evident that young people do value different dimensions of learning when they learn. This appreciation is an important component of young people's readiness to learn in an uncertain future. To equip our young people even more securely for their century, it is incumbent on all engaged with post-compulsory education to nurture a broad perception of learning.

\section{References}

BIS (Department for Business, Innovation and Skills) 2015. Reviewing Post 16 Education and Training Institutions. 
https://www.gov.uk/government/uploads/system/uploads/attachment_data/file/446516/BIS15-433-reviewing-post-16-education-policy.pdf

BPS (British Psychological Society) 2006. Code of Ethics and Conduct. Leicester: BPS.

Bransford, J., A. Brown, and R.Cocking. 1999. How People Learn: Brain, Mind, Experience and School. Washington: National Academy Press.

Brown, A. 1997. "Transforming Schools into Communities of Thinking and Learning about Serious Matters". American Psychologist. 52 (4): 399 - 413.

CBI (Confederation of British Industry) 2015. Inspiring Growth: CBI/Pearson Education and Skills Survey 2015. London: CBI.

Claxton, G. 2002. Building Learning Power. Bristol: TLO Limited.

Claxton, G. 2007. "Expanding Young People's Capacity to Learn”. British Journal of Educational Studies. 55 (2): [Taylor \& Francis, Ltd., Society for Educational Studies]: 11534. http://www.jstor.org/stable/4620549.

Claxton, G. 2013. School as an Epistemic Apprenticeship: The Case of Building Learning Power. Leicester: British Psychological Society.

Coffield, F. 2002. "Skills for the Future: I've got a little list". Assessment in Education. 9 (1): 39 - 43. DOI: 10.1080/09695940220119157

Coffield, F. 2007. Running Ever Faster Down the Wrong Road. London: Institute of Education.

DCSF (Department for Children, Schools and Families) 2008. Delivering 14 - 19 Reform: Next Steps Summary. London: DCSF.

DfE (Department for Education) 2015. 2010 - 2015 Government Policy: Young People. https://www.gov.uk/government/publications/2010-to-2015-government-policy-youngpeople/2010-to-2015-government-policy-young-people

DfE (Department for Education) 2015a. Official Statistics.

https://www.gov.uk/government/uploads/system/uploads/attachment_data/file/493181/SFR05 2016_Text.pdf

DfE (Department for Education) 2015b. Education and Training Statistics for the UK: 2015. https://www.gov.uk/government/uploads/system/uploads/attachment_data/file/473858/SR43 2015_Main_Text.pdf

DfE (Department for Education) 2015c. Review of Vocational Education, 2011: The Wolf Report: Recommendations final progress report.

https://www.gov.uk/government/uploads/system/uploads/attachment_data/file/405986/Wolf_ Recommendations_Progress_Report_February_2015_v01.pdf

DfE (Department for Education) 2016. Reformed GCSE, AS and A level Subject Content Government Consultation Response https://www.gov.uk/government/uploads/system/uploads/attachment_data/file/493404/Refor med_GCSE_AS_and_A_level_subject_content_consultation_government_response.pdf 
Dweck, C. 2006. Mindset: How You Can Fulfil Your Potential. New York: Random House.

Erikson, E. 1968. Identity, Youth and Crisis. London: Faber and Faber.

Field, A. 2009. Discovering Statistics Using SPSS 3rd Edition. London Sage.

Fredriksson, U. and B. Hoskins. 2007. "The Development of Learning to Learn in a European context". The Curriculum Journal. 18 (2): 127 - 134. DOI: 10.1080/09585170701445921

Freud, S. 1962. Two Short Accounts of Psycho-analysis. London: Pelican.

Garcia, T. and P. Pintrich. 1994. "Regulation, Motivation and Cognition in the Classroom: The Role of Self-schemas and Self-Regulatory Strategies". In Self Regulation of Learning and Performance, edited by D. Schunk, and B. Zimmerman, 127-153. New Jersey: Lawrence Erlbaum Associates.

Green, S.B., N.J. Salkind, and T.M. Akey. 2000. Using SPSS for Windows. Analysing and Understanding Data $2^{\text {nd }}$ Edition. New Jersey: Prentice Hall.

Hodgson A. and K. Spours. 2011. "Editorial: Policy for the Education and Training of 14 to 19 Year Olds in the UK - New Uncertainties and New Divisions?" London Review of Education 9 (2): 145 - 151. DOI: 10.1080/14748460.2011.585874.

Hodgson, A. 2015. The Coming of Age for FE? Reflections on the Past and Future Role of Further Education Colleges in England. London: Institute of Education Press.

Illeris, K. 2007. How we Learn: Learning and Non-Learning in School and Beyond. Abingdon: Routledge.

Illeris, K. 2015. "The Development of a Comprehensive and Coherent Theory of Learning". European Journal of Education, 50: 29-40. doi: 10.1111/ejed.1210

Kolb, D. 1984. Experiential Learning: Experience as the Source of Learning and Development. Englewood Cliffs, NJ: Prentice-Hall.

Lucas, B. and G. Claxton. 2010. New Kinds of Smart. Open University Press: Berkshire.

McQueen, H. and J. Webber. 2013. "What is an Effective Learner? A Comparison of Further Education Students' Views with a Theoretical Construction of Effective Learners.' Journal of Further and Higher Education 37 (5): 715-735 DOI: 10.1080/0309877X.2012.684040.

Organisation for Economic Co-operation and Development (OECD) 2015 The ABC of Gender Equality in Education: Aptitude, Behaviour, Confidence. OECD: Paris.

Piaget, J. 1952. The Child's Concept of Number. London: Routledge and Kegan Paul.

Pring, R., G. Haywards, A. Hodgson, J. Johnson, E. Keep, A. Oancea, G. Rees, K. Spours, and S. Wilde. 2009. Education for all: The future of Education and Training for $14-19$ year olds. London: Routledge.

Rust, J. and S. Golombok. 2009. Modern Psychometrics: The Science of Psychological Assessment. 3rd Edition. Hove: Routledge.

Watkins, C., E. Carnell, and C. Lodge. 2007. Effective Learning in Classrooms. London: Paul Chapman Publishing. 
Watkins, C. Forthcoming. "Developing learning-centred classrooms and schools". In International Handbook on Life in Schools and Classrooms: Past, Present and Future Visions, edited by Myhill, M., and R. Maclean. New York: Springer:

Wenger, E. 1998. Communities of Practice: Learning, Meaning and Identity. Cambridge, MA: Cambridge University Press.

Wolf, A. 2011. Review of Vocational Education - The Wolf Report. London: The Stationary Office. 
Table 1. Items for the content dimension of learning, percentage frequency of response, the mean scores and standard deviations.

\begin{tabular}{|c|c|c|c|c|c|c|c|}
\hline Item & $\begin{array}{c}\text { S D } \\
(\%)\end{array}$ & $\begin{array}{r}\mathrm{D} \\
(\%)\end{array}$ & $\begin{array}{c}A \\
(\%)\end{array}$ & $\begin{array}{l}\text { SA } \\
(\%)\end{array}$ & $M$ & $S D$ & $\mathbf{N}$ \\
\hline $\begin{array}{l}\text { Statement }(\text { St).50. I am } \\
\text { sure I will not need to } \\
\text { learn new information to } \\
\text { go forward in life. }(R)^{*}\end{array}$ & $\begin{array}{c}41.6 \\
(137)\end{array}$ & $\begin{array}{c}45.3 \\
(149)\end{array}$ & $\begin{array}{l}10.0 \\
(33)\end{array}$ & $\begin{array}{c}3.0 * * \\
(10)\end{array}$ & 3.26 & .79 & 329 \\
\hline $\begin{array}{l}\text { St.57***. If I want to get a } \\
\text { good job, or go to } \\
\text { university, I'm going to } \\
\text { need to show that I have } \\
\text { lots of knowledge in my } \\
\text { head. }\end{array}$ & $\begin{array}{l}1.2 \\
(4)\end{array}$ & $\begin{array}{c}8.8 \\
(29)\end{array}$ & $\begin{array}{c}54.3 \\
(178)\end{array}$ & $\begin{array}{c}35.7 \\
(117)\end{array}$ & 3.24 & .66 & 328 \\
\hline $\begin{array}{l}\text { St.45. I think that } \\
\text { employers value good } \\
\text { qualification grades that } \\
\text { show them what I know. }\end{array}$ & $\begin{array}{l}0.9 \\
(3)\end{array}$ & $\begin{array}{c}8.2 \\
(27)\end{array}$ & $\begin{array}{c}57.4 \\
(189)\end{array}$ & $\begin{array}{c}33.4 \\
(110)\end{array}$ & 3.23 & .63 & 329 \\
\hline $\begin{array}{l}\text { St.52. I think when I leave } \\
\text { here, I will build on the } \\
\text { knowledge I have learned } \\
\text { with new knowledge. }\end{array}$ & $\begin{array}{l}0.6 \\
(2)\end{array}$ & $\begin{array}{c}8.9 \\
(29)\end{array}$ & $\begin{array}{c}66.9 \\
(218)\end{array}$ & $\begin{array}{l}23.6 \\
(77)\end{array}$ & 3.13 & .58 & 326 \\
\hline $\begin{array}{l}\text { St.48. There is so much } \\
\text { information to understand } \\
\text { that I think learning is } \\
\text { something that I will do } \\
\text { throughout my life. }\end{array}$ & $\begin{array}{c}4.0 \\
(13)\end{array}$ & $\begin{array}{l}12.6 \\
(41)\end{array}$ & $\begin{array}{c}56.9 \\
(185)\end{array}$ & $\begin{array}{l}26.5 \\
(86)\end{array}$ & 3.06 & .74 & 325 \\
\hline $\begin{array}{l}\text { St.49. I try to make } \\
\text { connections between what } \\
\text { I have just learned and } \\
\text { what I already know. }\end{array}$ & $\begin{array}{l}1.5 \\
(5)\end{array}$ & $\begin{array}{l}12.0 \\
(39)\end{array}$ & $\begin{array}{c}66.0 \\
(215)\end{array}$ & $\begin{array}{l}20.6 \\
(67) \\
\end{array}$ & 3.06 & .62 & 326 \\
\hline $\begin{array}{l}\text { St.43. I am not enjoying } \\
\text { what I am learning at } \\
\text { college right now. }(R)\end{array}$ & $\begin{array}{c}31.1 \\
(101)\end{array}$ & $\begin{array}{c}47.7 \\
(155)\end{array}$ & $\begin{array}{l}15.7 \\
(51)\end{array}$ & $\begin{array}{c}5.5 \\
(18) \\
\end{array}$ & 3.04 & .83 & 325 \\
\hline $\begin{array}{l}\text { St.10. I have a strong } \\
\text { drive to do best in all my } \\
\text { studies. }\end{array}$ & $\begin{array}{l}2.4 \\
(8)\end{array}$ & $\begin{array}{l}18.5 \\
(61)\end{array}$ & $\begin{array}{c}53.3 \\
(176)\end{array}$ & $\begin{array}{l}25.8 \\
(85)\end{array}$ & 3.02 & .76 & 330 \\
\hline $\begin{array}{l}\text { St.58. When I get an } \\
\text { assignment back, I go over } \\
\text { it carefully correcting all } \\
\text { the errors and trying to } \\
\text { understand where I made } \\
\text { mistakes. }\end{array}$ & $\begin{array}{l}2.1 \\
(7)\end{array}$ & $\begin{array}{c}18.4 \\
(60)\end{array}$ & $\begin{array}{c}55.5 \\
(181)\end{array}$ & $\begin{array}{l}23.9 \\
(78)\end{array}$ & 3.01 & .72 & 326 \\
\hline $\begin{array}{l}\text { St.12. I try to relate what I } \\
\text { have learned in lessons to } \\
\text { something I already know. }\end{array}$ & $\begin{array}{l}1.8 \\
(6)\end{array}$ & $\begin{array}{l}14.9 \\
(49)\end{array}$ & $\begin{array}{c}64.9 \\
(213)\end{array}$ & $\begin{array}{l}18.3 \\
(60)\end{array}$ & 3.00 & .64 & 328 \\
\hline
\end{tabular}




\begin{tabular}{|c|c|c|c|c|c|c|c|}
\hline $\begin{array}{l}\text { St.29. I find that learning } \\
\text { can give me a deep sense } \\
\text { of personal satisfaction. }\end{array}$ & $\begin{array}{c}5.2 \\
(17)\end{array}$ & $\begin{array}{l}13.5 \\
(44)\end{array}$ & $\begin{array}{c}60.3 \\
(196)\end{array}$ & $\begin{array}{l}20.9 \\
(68)\end{array}$ & 2.97 & .75 & 325 \\
\hline $\begin{array}{l}\text { St.54. In Year } 10 \text { and/or } \\
11, \text { I found it was always } \\
\text { important to know as } \\
\text { much as possible. }\end{array}$ & $\begin{array}{c}3.4 \\
(11)\end{array}$ & $\begin{array}{l}18.4 \\
(60)\end{array}$ & $\begin{array}{c}57.5 \\
(188)\end{array}$ & $\begin{array}{l}20.6 \\
(67)\end{array}$ & 2.95 & .72 & 326 \\
\hline $\begin{array}{l}\text { St.16. When I was in Year } \\
10 \text { and /or } 11, \text { I learned } \\
\text { things by going over and } \\
\text { over them until I knew } \\
\text { them by heart. }\end{array}$ & $\begin{array}{c}6.4 \\
(21) \\
\end{array}$ & $\begin{array}{l}24.1 \\
(79) \\
\end{array}$ & $\begin{array}{c}48.2 \\
(158) \\
\end{array}$ & $\begin{array}{l}21.3 \\
(70) \\
\end{array}$ & 2.84 & .83 & 328 \\
\hline $\begin{array}{l}\text { St.21. I try to apply ideas } \\
\text { from lessons to other } \\
\text { activities. }\end{array}$ & $\begin{array}{l}2.1 \\
(7) \\
\end{array}$ & $\begin{array}{l}25.5 \\
(84)\end{array}$ & $\begin{array}{c}60.8 \\
(200)\end{array}$ & $\begin{array}{l}11.6 \\
(38)\end{array}$ & 2.82 & .65 & 329 \\
\hline $\begin{array}{l}\text { St.19. I am not interested } \\
\text { in learning information for } \\
\text { the sake of it. }(R)\end{array}$ & $\begin{array}{l}19.0 \\
(62) \\
\end{array}$ & $\begin{array}{c}48.9 \\
(160)\end{array}$ & $\begin{array}{l}26.0 \\
(85)\end{array}$ & $\begin{array}{c}6.1 \\
(20) \\
\end{array}$ & 2.81 & .81 & 327 \\
\hline $\begin{array}{l}\text { St.5. I memorise key } \\
\text { words, to remind me of } \\
\text { important concepts in } \\
\text { lessons. }\end{array}$ & $\begin{array}{c}5.5 \\
(18)\end{array}$ & $\begin{array}{l}21.8 \\
(72)\end{array}$ & $\begin{array}{c}61.2 \\
(202)\end{array}$ & $\begin{array}{l}11.5 \\
(38)\end{array}$ & 2.79 & .71 & 330 \\
\hline $\begin{array}{l}\text { St.27. I test myself on } \\
\text { important topics until I } \\
\text { understand them } \\
\text { completely. }\end{array}$ & $\begin{array}{c}3.0 \\
(10)\end{array}$ & $\begin{array}{c}31.6 \\
(104)\end{array}$ & $\begin{array}{c}50.5 \\
(166)\end{array}$ & $\begin{array}{l}14.9 \\
(49)\end{array}$ & 2.77 & .73 & 329 \\
\hline $\begin{array}{l}\text { St.36. When I was doing } \\
\text { my GCSEs, I thought } \\
\text { learning was about } \\
\text { absorbing facts. }\end{array}$ & $\begin{array}{c}4.9 \\
(16) \\
\end{array}$ & $\begin{array}{l}29.4 \\
(96)\end{array}$ & $\begin{array}{c}52.9 \\
(173)\end{array}$ & $\begin{array}{l}12.8 \\
(42) \\
\end{array}$ & 2.74 & .74 & 327 \\
\hline $\begin{array}{l}\text { St.20. Soon after a lesson, } \\
\text { I think over what we have } \\
\text { learned to make sure I } \\
\text { understand it. }\end{array}$ & $\begin{array}{c}7.3 \\
(24)\end{array}$ & $\begin{array}{c}37.6 \\
(123)\end{array}$ & $\begin{array}{c}49.2 \\
(161)\end{array}$ & $\begin{array}{c}5.8 \\
(19)\end{array}$ & 2.54 & .72 & 327 \\
\hline $\begin{array}{l}\text { St.7. I tend to learn what is } \\
\text { set, I usually don't do } \\
\text { anything extra. }(R)\end{array}$ & $\begin{array}{c}4.6 \\
(15)\end{array}$ & $\begin{array}{c}40.6 \\
(132)\end{array}$ & $\begin{array}{c}46.5 \\
(151)\end{array}$ & $\begin{array}{c}8.3 \\
(27)\end{array}$ & 2.42 & .71 & 325 \\
\hline $\begin{array}{l}\text { St.51. Soon after a lesson, } \\
\text { I re-read my notes to make } \\
\text { sure I understand them. }\end{array}$ & $\begin{array}{c}9.0 \\
(29)\end{array}$ & $\begin{array}{c}51.9 \\
(168)\end{array}$ & $\begin{array}{c}36.7 \\
(119)\end{array}$ & $\begin{array}{l}2.5 \\
(8)\end{array}$ & 2.33 & .67 & 324 \\
\hline
\end{tabular}

*Note $(\mathrm{R})$ indicates that the scores for the statement have been reversed when calculating the mean.

**Percentages are rounded to one decimal point. ***Note St 57 indicates the order of the statement in the questionnaire. 
Table 2. Items for the social dimension of learning, percentage frequency of response, the mean scores and standard deviations.

\begin{tabular}{|c|c|c|c|c|c|c|c|}
\hline Item & $\begin{array}{l}\text { S D } \\
(\%)\end{array}$ & $\begin{array}{c}D \\
(\%)\end{array}$ & $\begin{array}{c}A \\
(\%)\end{array}$ & $\begin{array}{l}\text { SA } \\
(\%)\end{array}$ & $M$ & $S D$ & $\mathbf{N}$ \\
\hline $\begin{array}{l}\text { St.40. It is so competitive } \\
\text { today that to get a good job } \\
\text { you need to show you are } \\
\text { really willing to work with } \\
\text { others. }\end{array}$ & $\begin{array}{c}1.2 * * \\
(4)\end{array}$ & $\begin{array}{c}7.0 \\
(23)\end{array}$ & $\begin{array}{c}49.8 \\
(164)\end{array}$ & $\begin{array}{c}41.9 \\
(138)\end{array}$ & 3.33 & .66 & 329 \\
\hline $\begin{array}{l}\text { St.26. I like it when } \\
\text { teachers give us time to ask } \\
\text { questions about stuff we } \\
\text { don't understand. }\end{array}$ & $\begin{array}{l}2.1 \\
(7)\end{array}$ & $\begin{array}{l}10.1 \\
(33)\end{array}$ & $\begin{array}{c}50.8 \\
(166)\end{array}$ & $\begin{array}{c}37.0 \\
(121)\end{array}$ & 3.23 & .71 & 327 \\
\hline $\begin{array}{l}\text { St.56. I know that being } \\
\text { asked questions in class is } \\
\text { good for my learning. }\end{array}$ & $\begin{array}{l}2.1 \\
(7)\end{array}$ & $\begin{array}{c}7.1 \\
(23) \\
\end{array}$ & $\begin{array}{l}59.5 \\
(194)\end{array}$ & $\begin{array}{l}31.3 \\
(102)\end{array}$ & 3.20 & .66 & 326 \\
\hline $\begin{array}{l}\text { St.17. I do not look } \\
\text { forward to having to learn } \\
\text { with others in the future. } \\
(R)^{*}\end{array}$ & $\begin{array}{l}29.4 \\
(96)\end{array}$ & $\begin{array}{c}58.6 \\
(191)\end{array}$ & $\begin{array}{c}9.8 \\
(32))\end{array}$ & $\begin{array}{l}2.1 . \\
(7))\end{array}$ & 3.15 & .68 & 326 \\
\hline $\begin{array}{l}\text { St.32. I think if I ask a } \\
\text { teacher or my friends a } \\
\text { question it shows that I am } \\
\text { not very smart. }(R)\end{array}$ & $\begin{array}{c}33.3 \\
(109)\end{array}$ & $\begin{array}{c}46.8 \\
(153)\end{array}$ & $\begin{array}{l}14.4 \\
(47)\end{array}$ & $\begin{array}{c}5.5 \\
(18)\end{array}$ & 3.08 & .83 & 327 \\
\hline $\begin{array}{l}\text { St.24. I like to learn with } \\
\text { other people. }\end{array}$ & $\begin{array}{l}2.4 \\
(8)\end{array}$ & $\begin{array}{l}12.8 \\
(42)\end{array}$ & $\begin{array}{c}66.1 \\
(216)\end{array}$ & $\begin{array}{l}18.7 \\
(61)\end{array}$ & 3.01 & .64 & 327 \\
\hline $\begin{array}{l}\text { St.13. Even though the } \\
\text { times are tough, I think I } \\
\text { will be able to get a good } \\
\text { job because I show that I } \\
\text { am willing to learn with } \\
\text { others. }\end{array}$ & $\begin{array}{c}3.1 \\
(10)\end{array}$ & $\begin{array}{l}15.0 \\
(49)\end{array}$ & $\begin{array}{c}60.2 \\
(197)\end{array}$ & $\begin{array}{l}21.7 \\
(71)\end{array}$ & 3.01 & .64 & 327 \\
\hline $\begin{array}{l}\text { St.4. I find learning with } \\
\text { others in sixth form a } \\
\text { hassle. }(R)\end{array}$ & $\begin{array}{l}20.1 \\
(66)\end{array}$ & $\begin{array}{c}62.5 \\
(205)\end{array}$ & $\begin{array}{l}13.7 \\
(45)\end{array}$ & $\begin{array}{c}3.7 \\
(12)\end{array}$ & 2.99 & .70 & 328 \\
\hline $\begin{array}{l}\text { St.28. I don't like to talk } \\
\text { about what I have learned. } \\
(R)\end{array}$ & $\begin{array}{l}21.3 \\
(70)\end{array}$ & $\begin{array}{c}50.2 \\
(165)\end{array}$ & $\begin{array}{l}24.6 \\
(81)\end{array}$ & $\begin{array}{l}4.0 \\
(13)\end{array}$ & 2.89 & .80 & 329 \\
\hline $\begin{array}{l}\text { St.44. I always ask } \\
\text { questions if I need to } \\
\text { understand something. }\end{array}$ & $\begin{array}{c}5.7 \\
(19)\end{array}$ & $\begin{array}{l}20.5 \\
(68)\end{array}$ & $\begin{array}{c}52.9 \\
(175)\end{array}$ & $\begin{array}{l}20.8 \\
(69)\end{array}$ & 2.89 & .80 & 331 \\
\hline $\begin{array}{l}\text { St.2. The course/s I am } \\
\text { doing now has made me } \\
\text { realise how enjoyable it is } \\
\text { to learn with others. }\end{array}$ & $\begin{array}{l}2.7 \\
(9) \\
\end{array}$ & $\begin{array}{l}23.3 \\
(77) \\
\end{array}$ & $\begin{array}{c}59.1 \\
(195)\end{array}$ & $\begin{array}{l}14.8 \\
(49) \\
\end{array}$ & 2.86 & .69 & 330 \\
\hline
\end{tabular}




\begin{tabular}{|c|c|c|c|c|c|c|c|}
\hline $\begin{array}{l}\text { St.33. When I was in Year } \\
10 \text { and/or } 11 \text {, I found } \\
\text { learning to be best when I } \\
\text { had someone to talk over } \\
\text { the learning with. }\end{array}$ & $\begin{array}{l}1.5 \\
(5)\end{array}$ & $\begin{array}{l}27.9 \\
(90)\end{array}$ & $\begin{array}{c}55.7 \\
(180)\end{array}$ & $\begin{array}{l}14.9 \\
(48)\end{array}$ & 2.84 & .68 & 323 \\
\hline $\begin{array}{l}\text { St.6. To be a good learner } \\
\text { in the future, I will talk } \\
\text { over new information with } \\
\text { friends. }\end{array}$ & $\begin{array}{c}3.7 \\
(12)\end{array}$ & $\begin{array}{l}21.8 \\
(71)\end{array}$ & $\begin{array}{c}65.3 \\
(213)\end{array}$ & $\begin{array}{c}9.2 \\
(30)\end{array}$ & 2.80 & .65 & 326 \\
\hline $\begin{array}{l}\text { St.41. In class, I feel I am } \\
\text { part of something } \\
\text { meaningful when I am } \\
\text { discussing subjects with } \\
\text { other people. }\end{array}$ & $\begin{array}{c}4.3 \\
(14) \\
\end{array}$ & $\begin{array}{l}23.1 \\
(76)\end{array}$ & $\begin{array}{c}62.0 \\
(204)\end{array}$ & $\begin{array}{l}10.6 \\
(35)\end{array}$ & 2.79 & .68 & 329 \\
\hline $\begin{array}{l}\text { St.15. I can't wait to leave } \\
\text { sixth form/college so that I } \\
\text { no longer have to ask or } \\
\text { answer any questions. }(R)\end{array}$ & $\begin{array}{l}18.0 \\
(58)\end{array}$ & $\begin{array}{c}50.0 \\
(161)\end{array}$ & $\begin{array}{l}21.4 \\
(69)\end{array}$ & $\begin{array}{l}10.6 \\
(34)\end{array}$ & 2.75 & .87 & 322 \\
\hline $\begin{array}{l}\text { St.31. In Year } 10 \text { and/or } \\
11, \text { the lessons I enjoyed } \\
\text { the least were the ones } \\
\text { where we were put into } \\
\text { groups. }(R)\end{array}$ & $\begin{array}{l}17.7 \\
(58)\end{array}$ & $\begin{array}{c}45.1 \\
(148)\end{array}$ & $\begin{array}{l}25.3 \\
(83)\end{array}$ & $\begin{array}{l}11.9 \\
(39)\end{array}$ & 2.69 & .90 & 328 \\
\hline $\begin{array}{l}\text { St.18. When I want to learn } \\
\text { something, I seek out } \\
\text { friends to study with. }\end{array}$ & $\begin{array}{c}7.1 \\
(23)\end{array}$ & $\begin{array}{c}39.5 \\
(128)\end{array}$ & $\begin{array}{c}46.9 \\
(152)\end{array}$ & $\begin{array}{c}6.5 \\
(21)\end{array}$ & 2.53 & .72 & 324 \\
\hline $\begin{array}{l}\text { St.37. When I am learning } \\
\text { at home, I talk over what I } \\
\text { am learning with my } \\
\text { friends or parents. }\end{array}$ & $\begin{array}{l}15.2 \\
(50)\end{array}$ & $\begin{array}{c}42.2 \\
(139)\end{array}$ & $\begin{array}{c}35.6 \\
(117)\end{array}$ & $\begin{array}{c}7.0 \\
(23)\end{array}$ & 2.34 & .82 & 329 \\
\hline $\begin{array}{l}\text { St.46. Even if I have } \\
\text { trouble learning the } \\
\text { material in lessons, I try to } \\
\text { do the work on my own, } \\
\text { without help from anyone. } \\
(R)\end{array}$ & $\begin{array}{c}4.3 \\
(14)\end{array}$ & $\begin{array}{l}28.5 \\
(93)\end{array}$ & $\begin{array}{c}55.2 \\
(180)\end{array}$ & $\begin{array}{l}12.0 \\
(39)\end{array}$ & 2.25 & .72 & 326 \\
\hline
\end{tabular}


Table 3. Items for the incentive dimension of learning, percentage frequency of response, the mean scores and standard deviations.

\begin{tabular}{|c|c|c|c|c|c|c|c|}
\hline Item & $\begin{array}{l}\text { S D } \\
(\%)\end{array}$ & $\begin{array}{c}\mathrm{D} \\
(\%)\end{array}$ & $\begin{array}{c}\mathbf{A} \\
(\%)\end{array}$ & $\begin{array}{l}\text { SA } \\
(\%)\end{array}$ & $M$ & $S D$ & $\mathbf{N}$ \\
\hline $\begin{array}{l}\text { St.1. I am motivated to be } \\
\text { the best that I can be, just } \\
\text { for myself. }\end{array}$ & $\begin{array}{c}0.9 * * \\
(3)\end{array}$ & $\begin{array}{l}14.3 \\
(47)\end{array}$ & $\begin{array}{c}55.6 \\
(183)\end{array}$ & $\begin{array}{l}29.2 \\
(96)\end{array}$ & 3.13 & .68 & 329 \\
\hline $\begin{array}{l}\text { St.55. I don't think that I } \\
\text { need to be in the right } \\
\text { mood to learn } \\
\text { successfully. }(R)^{*}\end{array}$ & $\begin{array}{c}32.8 \\
(107)\end{array}$ & $\begin{array}{c}47.5 \\
(155)\end{array}$ & $\begin{array}{l}16.3 \\
(53)\end{array}$ & $\begin{array}{c}3.4 \\
(11)\end{array}$ & 3.10 & .79 & 326 \\
\hline $\begin{array}{l}\text { St.53. I don't really want } \\
\text { to be doing the course/s I } \\
\text { am doing, and so staying } \\
\text { motivated is difficult. }(R)\end{array}$ & $\begin{array}{l}29.9 \\
(97)\end{array}$ & $\begin{array}{c}46.6 \\
(151)\end{array}$ & $\begin{array}{l}16.4 \\
(53)\end{array}$ & $\begin{array}{c}7.1 \\
(23)\end{array}$ & 2.99 & .87 & 324 \\
\hline $\begin{array}{l}\text { St.38. I am not a good } \\
\text { student; I am always } \\
\text { behind with my } \\
\text { assignments. }(R)\end{array}$ & $\begin{array}{c}32.6 \\
(106)\end{array}$ & $\begin{array}{c}38.5 \\
(125)\end{array}$ & $\begin{array}{l}20.9 \\
(68)\end{array}$ & $\begin{array}{c}8.0 \\
(26)\end{array}$ & 2.96 & .93 & 325 \\
\hline $\begin{array}{l}\text { St.23. When I was doing } \\
\text { my GCSEs, I was very } \\
\text { motivated to get good } \\
\text { grades. }\end{array}$ & $\begin{array}{c}5.8 \\
(19)\end{array}$ & $\begin{array}{l}24.0 \\
(78)\end{array}$ & $\begin{array}{c}42.8 \\
(139)\end{array}$ & $\begin{array}{l}27.4 \\
(89) \\
\end{array}$ & 2.92 & .86 & 325 \\
\hline $\begin{array}{l}\text { St.8. The course/s I am on } \\
\text { is so interesting, I am very } \\
\text { happy to study for it. }\end{array}$ & $\begin{array}{r}4.9 \\
(16) \\
\end{array}$ & $\begin{array}{l}19.4 \\
(63) \\
\end{array}$ & $\begin{array}{c}56.2 \\
(182) \\
\end{array}$ & $\begin{array}{l}19.4 \\
(63) \\
\end{array}$ & 2.90 & .76 & 324 \\
\hline $\begin{array}{l}\text { St.34. To do my best when } \\
\text { I am learning, I often take } \\
\text { small breaks so that I can } \\
\text { stay calm. }\end{array}$ & $\begin{array}{c}5.1 \\
(17)\end{array}$ & $\begin{array}{l}19.9 \\
(66)\end{array}$ & $\begin{array}{c}55.6 \\
(184)\end{array}$ & $\begin{array}{l}19.3 \\
(64) \\
\end{array}$ & 2.89 & .77 & 331 \\
\hline $\begin{array}{l}\text { St.30. As I look to the } \\
\text { future, I am motivated to } \\
\text { find happiness through } \\
\text { learning. }\end{array}$ & $\begin{array}{c}3.6 \\
(12) \\
\end{array}$ & $\begin{array}{l}22.1 \\
(73)\end{array}$ & $\begin{array}{c}58.0 \\
(192)\end{array}$ & $\begin{array}{l}16.3 \\
(54) \\
\end{array}$ & 2.87 & .72 & 331 \\
\hline $\begin{array}{l}\text { St.35. My heart isn't in my } \\
\text { course/s at Sixth Form } \\
\text { college so I find it hard to } \\
\text { learn. }(R)\end{array}$ & $\begin{array}{l}26.3 \\
(86)\end{array}$ & $\begin{array}{c}41.3 \\
(135)\end{array}$ & $\begin{array}{l}23.2 \\
(76)\end{array}$ & $\begin{array}{c}9.2 \\
(30)\end{array}$ & 2.85 & .92 & 327 \\
\hline $\begin{array}{l}\text { St.14. In the future, I will } \\
\text { be very motivated to learn } \\
\text { only if my job depends on } \\
\text { it. }\end{array}$ & $\begin{array}{c}5.8 \\
(19)\end{array}$ & $\begin{array}{l}25.8 \\
(84)\end{array}$ & $\begin{array}{c}50.9 \\
(166)\end{array}$ & $\begin{array}{l}17.5 \\
(57)\end{array}$ & 2.80 & .79 & 326 \\
\hline $\begin{array}{l}\text { St.9. I think that GCSE } \\
\text { exams at school can be so } \\
\text { stressful it is difficult to } \\
\text { learn. }(R)\end{array}$ & $\begin{array}{l}18.3 \\
(60)\end{array}$ & $\begin{array}{c}47.0 \\
(154)\end{array}$ & $\begin{array}{l}26.2 \\
(86)\end{array}$ & $\begin{array}{c}8.5 \\
(28)\end{array}$ & 2.75 & .85 & 328 \\
\hline $\begin{array}{l}\text { St.47. I am motivated to do } \\
\text { well, so I try to work }\end{array}$ & & & & & 2.71 & .74 & 327 \\
\hline
\end{tabular}




\begin{tabular}{|c|c|c|c|c|c|c|c|}
\hline $\begin{array}{l}\text { solidly all the way through } \\
\text { the term. }\end{array}$ & $\begin{array}{l}5.2 \\
(17)\end{array}$ & $\begin{array}{l}30.3 \\
(99)\end{array}$ & $\begin{array}{c}52.6 \\
(172)\end{array}$ & $\begin{array}{l}11.9 \\
(39)\end{array}$ & & & \\
\hline $\begin{array}{l}\text { St.3. I find sixth } \\
\text { form/college learning } \\
\text { stressful, I don't want to } \\
\text { do any more than I have } \\
\text { to. }(R)\end{array}$ & $\begin{array}{l}12.8 \\
(42)\end{array}$ & $\begin{array}{c}44.7 \\
(147)\end{array}$ & $\begin{array}{c}34.3 \\
(113)\end{array}$ & $\begin{array}{c}8.2 \\
(27)\end{array}$ & 2.62 & .81 & 329 \\
\hline $\begin{array}{l}\text { St.42. I find thinking } \\
\text { about my future stressful } \\
\text { and it has a bad effect on } \\
\text { my learning. (R) }\end{array}$ & $\begin{array}{l}13.5 \\
(44)\end{array}$ & $\begin{array}{c}40.4 \\
(132)\end{array}$ & $\begin{array}{c}32.7 \\
(107)\end{array}$ & $\begin{array}{l}13.5 \\
(44)\end{array}$ & 2.54 & .89 & 327 \\
\hline $\begin{array}{l}\text { St.39. What I am learning } \\
\text { now is difficult; I must be } \\
\text { emotionally strong to } \\
\text { manage it. }\end{array}$ & $\begin{array}{l}13.8 \\
(45)\end{array}$ & $\begin{array}{c}35.4 \\
(115)\end{array}$ & $\begin{array}{c}40.3 \\
(131)\end{array}$ & $\begin{array}{l}10.5 \\
(34)\end{array}$ & 2.47 & .86 & 325 \\
\hline $\begin{array}{l}\text { St.25. I often get frustrated } \\
\text { in class and this stops me } \\
\text { from concentrating. }(R)\end{array}$ & $\begin{array}{l}10.9 \\
(36)\end{array}$ & $\begin{array}{c}36.2 \\
(119)\end{array}$ & $\begin{array}{c}32.5 \\
(107)\end{array}$ & $\begin{array}{l}20.4 \\
(67)\end{array}$ & 2.38 & .93 & 329 \\
\hline $\begin{array}{l}\text { St.22. I spend a lot of time } \\
\text { finding out about new } \\
\text { topics. }\end{array}$ & $\begin{array}{c}6.8 \\
(22) \\
\end{array}$ & $\begin{array}{c}54.3 \\
(176)\end{array}$ & $\begin{array}{c}33.6 \\
(109)\end{array}$ & $\begin{array}{r}5.2 \\
(17) \\
\end{array}$ & 2.37 & .69 & 324 \\
\hline $\begin{array}{l}\text { St.11. Young people are } \\
\text { having such a hard time at } \\
\text { the moment, it makes it } \\
\text { difficult to study. }(R)\end{array}$ & $\begin{array}{l}11.3 \\
(37) \\
\end{array}$ & $\begin{array}{l}27.3 \\
(89) \\
\end{array}$ & $\begin{array}{r}35.0 \\
(114) \\
\end{array}$ & $\begin{array}{l}26.4 \\
(86) \\
\end{array}$ & 2.24 & .99 & 326 \\
\hline
\end{tabular}


Table 4. The mean scores for the items categorised into three dimensions.

\begin{tabular}{|c|c|c|c|c|}
\hline $\begin{array}{l}\text { The learning } \\
\text { dimension }\end{array}$ & $\begin{array}{l}\text { Mean score } \\
\text { for all the } \\
\text { items. }\end{array}$ & $\begin{array}{c}\text { The } \\
\text { standard } \\
\text { deviation for } \\
\text { all the items. }\end{array}$ & $\begin{array}{c}\text { The Range } \\
\text { for all the } \\
\text { items. }\end{array}$ & $\begin{array}{r}\text { Number of } \\
\text { items. }\end{array}$ \\
\hline $\begin{array}{l}\text { The content } \\
\text { dimension of } \\
\text { learning. }\end{array}$ & 2.91 & .25 & .93 & 21 \\
\hline $\begin{array}{l}\text { The interaction } \\
\text { dimension of } \\
\text { learning. }\end{array}$ & 2.88 & .29 & 1.08 & 19 \\
\hline $\begin{array}{l}\text { The incentive } \\
\text { dimension of } \\
\text { learning. }\end{array}$ & 2.75 & .26 & .89 & 18 \\
\hline
\end{tabular}

